\title{
A Critical Discourse Analysis of an Editorial Article (The Audience Affecting the Writer's Ideology and Lexical Choice)
}

\author{
Sanaa Hssni Al-Marayat \\ Language Center, English Language Department, The University of Jordan, Amman, Jordan
}

\begin{abstract}
This paper reports on the findings of how the status of the audience affects the discourse of the writer in terms of the lexical choice and ideology. The data are elicited through a questionnaire that consists of (11) questions represent lexical choice and ideology. Analysis of the data suggests that there is a great support and satisfaction about the ideology of the editor more than some of the lexical choice questions. In addition, the editor was somewhat successful in reflecting what the audience thinks of. The study concludes with some implications and recommendations in the field of discourse analysis.
\end{abstract}

Index Terms - discourse analysis, ideology, lexical choice

\section{INTRODUCTION}

The domain of this paper is discourse analysis of newspaper editorial articles. In particular, it reports on how the status of the audience affects the discourse of the writer and to what extent the editorial satisfies their needs and beliefs. In this regard, Moji $(2011$, p. vi) stipulated that "... the language of Editorials may not be necessarily objective, it is also reader-centered and realized facts. Editorials also to employ [sic] language as means". When doing a piece of writing, the author should have "a communicative goal by modulating and fine-tuning one's text" (Alamargot et al. 2011, p. 505) based on "audience awareness" (p. 505). He should further take into consideration the miscellaneous kinds of audience whom they differ according to their religion, education and country. Gross (2012, p. 203) referred to this kind of audience as the "universal audience" whom they "consist of all rational beings; persuasive discourse addressed to these thematic [sic] facts and truths" (p. 203). For this sake, Rose (quoted in Gregg et al. 1989, p. 181) posited that writers have to "write in a cognitive and social vacuum".

McCrimmon (1963, p. 3) defines the process of writing as "a deliberate attempt by one person to communicate to others those ideas, facts, or impressions that will create to the results which the writer has intended to achieve". Witte and Faigley (1981, p. 199) argued that "the quality or "success" of a text ...depends a great deal on factors outside the text itself ".

According to them, writing quality is defined as "the "fit" of a particular text to its context, which includes such factors as the writer's purpose, the discourse medium, and audience's knowledge of an interest in the subject."

A significant factor which plays an essential role in the writing process is the Working Memory (WM). Alamargot et al. (2011, p. 506) affirmed the fact that "in the case of text composition, increased capacity could be expected to facilitate the storage of the communicative goal and the representation of the reader during the engagement of the writing processes".

Through analysis of the editorial article taken from the Jordan Times newspaper, the present research is intended to reveal how the writer should account for the audience's beliefs and needs in an international printed media with regard to the movie insulting prophet Mohammad-May peace be upon him. In other words, the study reported here examines how the national and international audience interacts with this piece of writing and to what extent this editorial meets their beliefs.

The theme of the movie insulting prophet Mohammed, May peace be upon him, was selected because of its recent prominence in Jordan and Jordan Press. So prominent was the subject of insulting the prophet in the months during the period in which the bulk data for this study was gathered that in a sense, it is no exaggeration to say that this theme selected itself. Indeed, the movie insulting the prophet was such a preoccupation of Jordan press during September 2012.

This paper proceeds as follows. Section II provides theoretical background. Section III presents the Literature review. Section IV specifies the study objectives. Methodology is described in Section V. Findings are presented and discussed in section VI, while conclusion and recommendations are provided in Section VII

\section{THEORETICAL BACKGROUND}

\section{A. Critical Discourse Analysis}


Critical Discourse Analysis (CDA), as a significant branch of discourse Analysis (DA), aims to trace the "cultural and ideological meaning in spoken and written texts" (O'Halloran, 2005, p. 1946). It takes into consideration the interaction between discourse and ideologies (Barletta Manjarres, 2007). Further, Wodak and Meyer (2001) points out that CDA accounts for investigating the relation between language, society and power. Such components play a signification role when interpreting a particular text.

Fairclough $(1995$, p. 7) viewed discourse as "... use of language seen as a form of social practice, and discourse analysis is analysis of how texts work within sociocultural practice". In short, Hall (2012, p. 16) defined CDA as "... the interface between speech acts in text and their subsequent effects on audiences."

There are three main approaches that deal with the communicative texts. These are Wodak's Discourse Historical Approach (1989), Fairclough's Social Discourse Approach (1995) and Van Dijk's Cognitive-discourse Approach (2006). The study in hand deals mainly with Van Dijk's Cognitive-discourse Approach (2006). This model is considered precise framework in studying ideologies as it combines political strategies, argumentation, semantic strategies, stylistic information and rhetorical devices (Rashidi and Souzandehfar, 2010).

\section{B. Working Memory}

Working Memory Capacity, abbreviated as WMC, has a very essential role in the process of writing "as a factor for individual differences in the ability to compose a text with communicative efficiency based on audience awareness" (Alamargot et al. 2011, p. 505). According to Baddeley (2003, p. 189), It "involves the temporary storage and manipulation of information that is assumed to be necessary for a wide range of complex cognitive activities." In one study conducted by Alamargot et al. (2011, p. 512), results confirmed that WM is the main factor that is responsible for the graduate to take the audience into account while composing a text.

\section{Audience: A Brief Account of Its Significance}

The interest in shedding the light on the importance of audience started in the 4th century BC. Cooper (quoted in Gregg et al. 1996, p. 121) denoted that the analysis of the audience along with its impact on the speaker first emerged in Aristotle's The Rhetoric. "Consider your audience" was the main focus of Aristotle's The Rhetoric. Ede (1979, p. 291) commented that "much of the Rhetoric is, in fact, concerned with ways of bringing rhetors and their audience closer together". Gregg et al. (1996, p. 121) summarized Aristotle's interest in the audience reporting that "the Aristotelian conceptualization of sense of audience is focused primarily on the writer's perception of the reader's (audience) needs rather than the dynamic interaction between the writer (self), audience (reader), and context".

Ede (1979, p. 291) argued "that teachers of written composition should place greater emphasis on the role of audience in discourse". In her study, Ede offered two responses "to the need for a more audience-centered approach to writing" (p. 291). Kroll (1984, p. 172) examined three views of audience which are the "rhetorical," "informational," and "social" perspectives. He explored the strengths and weaknesses of each one without preferring one over the other.

According to McQuail (1997, p. 1), ""audience" simply refers to the readers of, viewers of, listeners to one or other media channel or of this or that type of content or performance".

\section{LITERATURE REVIEW}

Below are several previous studies that are related to the current study in various ways. These studies are arranged logically rather than chronologically, i.e., they are arranged from general to specific according to their relationship with the present study.

Hallasa (2001) investigated "the use of adverbial clauses in the English language used in newspaper editorials" (p. ix). The study was based on the analysis of 56 texts taken from two English news papers; the international Herald Tribune and The Independent. Analysis of the data reported on the frequent use of complex sentences, finite and infinitival adverbial clauses, adverbial clauses embedded within a noun phrase and high frequency of adverbial clauses of time.

Al-Omari (2001) examined the problems found in the Friday sermons discourse in Irbid, Jordan. The data were elicited through 40 Friday sermons, recorded by audio cassettes. The findings showed that Friday sermons suffer from shortcomings in the coherence, cohesion, organization and unity which are the very essential discoursal qualities any Friday sermon.

Jawad (2002) held" a contrastive rhetorical analysis between The Jordan Times and The Guardian focusing on thought development and organization"(p. ix). The analysis of the study was based on the models developed by Connor and Lauer (1988) and Toulmin (1958) in terms of the superstructure of an argument and the informal reasoning, respectively. The study concluded that the same components such as situation, problem, solution and evaluation have been found between both The Jordan Times and The Guardian.

Yaghoobi (2009) explored how language and ideology are represented differently in the printed media, more specifically in an Iranian newspaper and an American magazine with opposing ideologies pertaining to Hizbullah-Israel last war in 2006.

Buja (2010) examined how "a text can be regarded as an interaction between writer and reader"(p. 85). The study was conducted based on a Romanian satirical newspaper, Academia Catavencu. Analysis of the data suggested that "the 
linear organization both at sentential level and at discourse level will influence the reader's interpretation of the discourse"(p. 92).

The study reported here presents a critical discourse analysis of the way that Jordan Times editors construct discourses, paying heed to the audiences' different religions, backgrounds and beliefs.

\section{OBJECTIVES}

This study seeks answers to the following questions:

(1) How does the status of the audience affect the discourse of the writer in terms of the lexical choice and ideology?

(2) How the composition of the writer is considered a reflection of the status of the public opinion in relation to the current issues and uprising stories?

(3) To what extent does the writer account for the beliefs of his diverse kind of readers?

\section{METHODS}

\section{A. Subjects}

The subjects were two different groups of readers at the University of Jordan. The first group (G1) comprises 15 national readers ( 8 females and 7 males), all Muslims. Their countries of origin are Jordan, Palestine and Egypt. The members of this group have a good English facility which enables them to read and interact with any kind of English text. The second group (G2) consists of 15 international readers ( 9 females and 6 males), 2 Muslims amongst. These are taking Arabic courses and they are holders of Bachelor degree or Master's degree Members of this group are from diverse countries like U.S.A., U.K., Sweden, Italy, India, Norway and Turkey. All in all, both groups are well educated and good followers of news editorials based on a question jotted down in the questionnaire.

\section{B. Data Selection and Sampling}

This study is conducted based on one editorial article taken from Jordanian international newspapers, namely the Jordan Times. The Jordan Times has been chosen as it is oriented to the international community which means mass audience who are diverse in their beliefs, religion and language.

The editorial was first read in their entirety for a sense of the whole, and memos were written about the content and style. Particular words and phrases were highlighted to alert the author's attention during the more careful line-by-line rereading of the text.

Accordingly, a questionnaire was designed. It consisted of (11) items, some involved lexical choice and others involved ideological ones. The items (1-4) represented lexical choice and (5-10). Question number (11) came as to assess the audience sense of the editorial identity (see appendix).

\section{Data Analysis}

This study was held so to determine whether or not the audience affects the discourse of the writer in terms of the lexical choice and ideology as well as to examine whether or not the writer account for the beliefs of his diverse kind of readers. Data were collected. They were analyzed through SPPS program so to extract the different statistical procedures such as the descriptive statistics. This is to describe and summarize the data.

\section{RESULTS AND DISCUSSION}

Table (1) provides the complete list of frequencies of the answers for each group of subjects on each question.

\begin{tabular}{|c|c|c|c|c|c|c|c|}
\hline \multicolumn{3}{|c|}{ Frequency } & \multicolumn{5}{|c|}{ Frequency } \\
\hline$\#$ & agree & it doesn't matter & disagree & agree & it do & & disagree \\
\hline \multicolumn{4}{|c|}{ G1 } & \multicolumn{4}{|c|}{ G2 } \\
\hline 1 & 5 & 3 & 7 & 6 & 2 & 7 & \\
\hline 2 & 12 & 0 & 3 & 12 & 1 & 2 & \\
\hline 3 & 0 & 3 & 12 & 3 & 7 & 5 & \\
\hline 4 & 8 & 3 & 4 & 6 & 4 & 5 & \\
\hline 5 & 14 & 1 & 0 & 13 & 0 & 2 & \\
\hline 6 & 14 & 0 & 1 & 14 & 0 & 1 & \\
\hline 7 & 13 & 2 & 0 & 13 & 1 & 1 & \\
\hline 8 & 15 & 0 & 0 & 14 & 0 & 1 & \\
\hline 9 & 13 & 1 & 1 & 14 & 0 & 1 & \\
\hline 10 & 14 & 0 & 1 & 12 & 2 & 1 & \\
\hline $\mathrm{Pe}$ & tage 16.02 & 1.95 & 4.35 & 16.05 & 2.55 & 3.9 & \\
\hline
\end{tabular}

A glance at the results exhibits that the total percentages of answers for each group on the options (agree), (it doesn't matter) and (disagree) are close. The attitude and reaction of the diverse audience with the text was quite the same, the 
readers were engaged, and remained so throughout the duration of this study. Accordingly, it is clear enough to claim that the editorial satisfies the audience's beliefs. To some degrees, the results reveal that the editor was trying to be neutral, objective and not bias since the editorial was straightforward. It emerged facts and showed what happened in reality as a reaction to the insulting movie.

Table (2) provides the complete list of the percentages of the answers for each group of subjects on each question.

\begin{tabular}{|c|c|c|c|c|c|c|}
\hline \multicolumn{3}{|c|}{ Frequency } & \multicolumn{4}{|c|}{ Frequency } \\
\hline$\#$ & agree it & doesn't matter & disagree & agree & it doesn't matter & disagree \\
\hline \multicolumn{4}{|c|}{ G1 } & \multicolumn{3}{|c|}{ G2 } \\
\hline 1 & 33.3 & 20 & 46.7 & 40 & 13.3 & 46.7 \\
\hline 2 & 80 & 0 & 20 & 80 & 6.7 & 13.4 \\
\hline 3 & o & 20 & 80 & 20 & 46.7 & 33.4 \\
\hline 4 & 53.3 & 20 & 26.7 & 40 & 26.7 & 33.3 \\
\hline 5 & 93.3 & 6.7 & 0 & 86.7 & $\mathrm{O}$ & 13.3 \\
\hline 6 & 93.3 & 0 & 6.7 & 93.3 & 0 & 6.7 \\
\hline 7 & 86.7 & 13.3 & 0 & 86.7 & 6.7 & 6.7 \\
\hline 8 & 100 & o & 0 & 93.3 & 0 & 6.7 \\
\hline 9 & 86.7 & 6.7 & 6.7 & 93.3 & 0 & 6.7 \\
\hline 10 & 93.3 & 0 & 6.7 & 80 & 13.3 & 6.7 \\
\hline
\end{tabular}

A further examination of table (2) indicates that the percentages of (agree) answers for the last five questions which represent ideology in both groups are higher than those of the lexical choice which represent the first four questions. In the light of this, it seems that there is a great support and satisfaction about the ideology of the editor more than some of the lexical choice questions. This indicates that the writer was somewhat successful in reflecting what the audience thinks of. For example, question (2) on the lexical choice displays similar percentage in both groups which is (80\%) believing that Palestinian are indigenous. However, one member in G2 said that; "of course I see them indigenous, but it might be a strong statement in a neutral newspaper". This consolidates the findings of previous researches that "audience is a physical, active presence in the discourse production process" (Johnson 1997, p. 364). In terms of question (1), both groups registered equal percentages of disagree, (46.7\%), on using the word Jewish instead of Zionist while $(33.3 \%)$ and $(40 \%)$ of G1 and G2 agree, respectively. This expresses a dissatisfaction of the audience with the editor's lexical choice of one word over the other.

Regarding question (3), none of the national Muslim readers answer (agree) about not using the phrase -May peace be upon him- right away after the word Prophet. (80\%) of them answer disagree upon not using it which is still a higher percentage than the (20\%) of those who agree in G2. They argue that the writer being an Arab and Muslim should use it and not "sugarcoat" words so that to satisfy the international readers as Islam is our religion and Mohammad is our prophet whether they like or not. This is something we should be proud of. The editor has to respect other's religion no matter what s/he believes in or his/her religion is. (46.7\%) of the international readers' answer came as (it doesn't matter), some commenting that "it is ok to use it if is important to the writer" and "it doesn't impress or harm me".

The option (it doesn't matter) gives an indication that even if the editor used the phrase it would not make any problem or affect the international audience, especially that $(80 \%)$ of the national Muslims readers show dissatisfaction upon not using it, (20\%) it doesn't matter and none agree. It is pretty clear here that the editor fails to account for the national Muslim readers pertaining to this point.

As to question (4), though the majority of both groups display agreement on the editor's description of the movie as a "US", they argue that "the editor's definition is very big" as "the movie was made in the US but it is not an official government policy." Therefore, the editor was not accurate and precise enough in his description. He should have been more careful in his/her lexical choice. Pertaining to question (11), (86.7\%) of the international readers think that the editorial was taken from an Eastern newspaper while (13.3\%) think that it is taken from a Western one. (53.3\%) of the national readers think the editorial taken from an Eastern newspaper and (46.7\%) of them think it belongs to a Western one. It is clearly evident that both groups registered the highest percentages thinking the editorial taken from an Eastern newspaper. Those who answer so argue that the editorial seems more like defending Islam and crediting Muslims against Israeli occupation and extremists who are actually creating violence. One of the international readers also commented that "it's favoring Muslim. The editor is not objective, fully agree though".

It might be safe to say that it is the editor's ideology which gives the audience a hunch about the nature of the editorial. Most international readers affirmed that the editor's ideologies reflect where he/she stands, though agree with them as this is the reality which sounds crystal clear to everybody. On the other hand, the national readers justified their answer of the editorial's nature as western commented that it is because of freedom of speech that the western newspapers have. Another one said that the editor may be a western one who is neutral and supporting our case.

It is clear here that each group has its own justifications and perspectives. Some members in (G1) evaluate the editorial as being neutral while others in $(\mathrm{G} 2)$ see it the other way round.

\section{CONCLUSION AND RECOMMENDATIONS}


The study in hand has reported on how the diversity of the audience plays a significant role in the discourse adapted by the writer. It is clear enough to claim that the editorial satisfies the audience's beliefs. To some degrees, results reveal that the editor was trying to be neutral, objective and not bias since the editorial was straightforward. It emerged facts and showed what happened in reality as a reaction to the insulting movie. This consolidates the findings of previous researches that "audience is a physical, active presence in the discourse production process" (Johnson 1997, p. 364).

Discussion of the data had led to the following conclusions. First, the editor should be objective as much as possible, showing facts no matter what he thinks. Second, the more international the editorial is, the more careful the editor should be while writing and choosing his words.

Due to the importance of the written media in affecting the audience's beliefs and perspectives, more specifically the newspapers editorials and in the light of the discussion and conclusions, the following recommendation may be suggested for editors in order to improve the discoursal level. Courses may be organized which aim to train editors about how to be more meticulous avoiding the problematic lexical choices that cause misunderstanding and vagueness in its context like the words used here "US movies" and "Jewish". It remains for further research as to assess and compare how articles penned by the same writer change and differ based on the audience addressed.

\section{APPENDIX}

\section{Nothing justifies murder}

\section{Sep 12, 2012 | 23:37 Updated: Sep 12, 2012 | 23:37}

A provocative US movie on Islam triggered acts of violence in Libya and Egypt, leading to the murder of the American ambassador to Libya along with three of his staff.

The perpetrators of the attack certainly knew the ambassador and the other victims had no role in the making of the movie, which, according to news reports, intended to depict Islam in a negative manner, a goal that the killers of the US diplomats are also serving.

One of the main missions of the murdered diplomats was to build a bridge between Libya and the US, between two parts of the world and two cultures. Their undertaking seems to have been lost on extremist elements that, wittingly or unwittingly, vindicated the goals of the producer of the movie "Innocence of Muslims".

There were conflicting reports on the idm, $\wedge$

8 entity and nationality of the producer, identified by an Associated Press report early Wednesday as Israeli Sam Bacile, with the agency later in the day shedding doubts on its earlier report. Regardless of the identity and the nationality, the producer certainly wished to sow hatred towards Muslims, just as it happens Israel, where one-fifth of the population - the indigenous Palestinians of which a majority Muslim - is facing discrimination.

In the earlier AP report, the alleged moviemaker described Islam as a cancer and said he wanted his film to be a provocative political statement condemning the religion. He said the two-hour $\$ 5$ million movie received financing from more than 100 Jewish donors who share his belief that the movie will help Israel "by exposing Islam's flaws to the world", according to the report.

Clearly stated, and regardless of the identity and nationality, the intentions are to denigrate Islam, the faith of more than 1.5 billion people, or around one quarter of the world's population, most of them living peacefully with followers of other faiths. The movie certainly targets these people in a manner that aims to disrupt their relations with others who might view them in a negative light.

Unfortunately such job sometimes is made easier by a very small minority of Muslims who advocate violence or the use of force to impose their views on others - others here being not only non-Muslims, but also Muslims who do not agree with them, meaning the vast majority of the followers of the faith.

This vast majority is victim of this small minority exactly as it is victim of this movie, produced to provoke, harm and cause rifts.

Muslims all over the world, who live in more than 200 countries and territories, should remember that their faith is that of peace and tolerance, that the Prophet and the caliphs instructed their armies not to kill innocent people, not even to cut trees or destroy houses.

They and others have to remember that this religion offered protection to messengers and ambassadors, as well as to all those living under the protection of any Muslim state, in times of war and peace.

In Islam and for Muslims, nothing justifies violence and spilling blood of innocent people.

Nothing justifies Wednesday's crime in Benghazi, and nothing and nobody should exonerate the filmmaker whose $\underline{\text { sinister objectives are very clear }}$

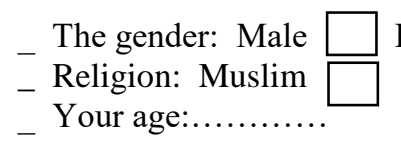

Female Non-Muslim

- Are you a follower reader of nev Reader

\section{The questionnaire}

_ Country of origin:.

- The educational level:.

Faculty:

newspaper editorials?

Non-reader 
The following questions are based on your reading for an editorial article entitled" Nothing justifies murder".

1. In the text, to what extent do you agree with the use of the word "Jewish" instead of the word Zionist? Strongly agree agree it doesn't matter disagree strongly disagree

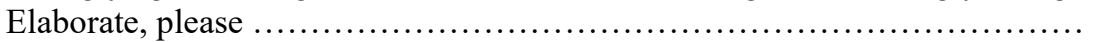

2. To what extent do you agree with the use of the word "indigenous" in the phrase" indigenous Palestinians"? Strongly agree agree it doesn't matter disagree strongly disagree Elaborate, please ...................................................

3. To what extent do you agree about not using the phrase-May peace be upon him- right away after the word "prophet "?

Strongly agree agree it doesn't matter disagree strongly disagree Elaborate, please ..................................................

4. To what extent do you agree with the use of the word "US" in the sentence" A provocative US movie on Islam triggered acts of violence ..."?

Strongly agree agree it doesn't matter disagree strongly disagree

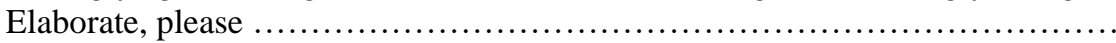

5. The editor of the editorial stated that "nobody should exonerate the filmmaker whose sinister objectives are very clear." To what extent do you agree?

Strongly agree agree it doesn't matter disagree strongly disagree

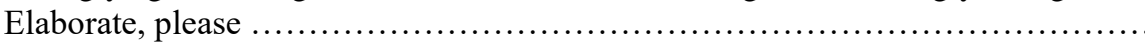

6. The editor mentioned that the producer of the movie wished to "sow hatred towards Muslim." To what extent do you agree with the sentence?

Strongly agree agree it doesn't matter disagree strongly disagree

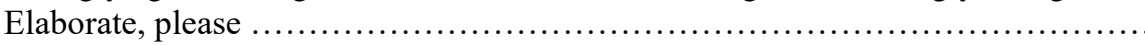

7. The editor mentioned that the producer of the movie wished to "denigrate Islam, the faith of more than 1.5billion people." To what extent do you agree with the sentence?

Strongly agree agree it doesn't matter disagree strongly disagree

Elaborate, please

8. The editor mentioned that the producer of the movie wished to "provoke, harm and cause rifts." To what extent do you agree with the sentence?
Strongly agree
agree it doesn't matter
disagree
strongly disagree

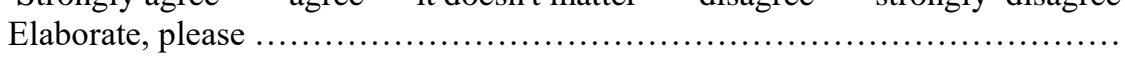

9. The editor stated that "The movie certainly targets these people in a manner that aims to disrupt their relations with others who might view them in a negative light." To what extent do you agree with the sentence?

Strongly agree agree it doesn't matter disagree strongly disagree Elaborate, please .................................................

10. The editor stated that "In Islam and for Muslims, nothing justifies violence and spilling blood of innocent people." To what extent do you agree with the sentence?

Strongly agree agree it doesn't matter disagree strongly disagree

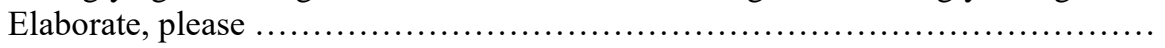

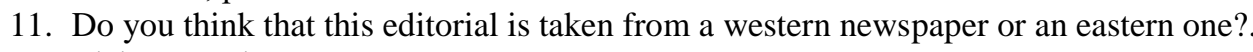

Elaborate, please

Thank you

\section{REFERENCES}

[1] Alamargot, D., G. Caporossi, D. Chesnet and C. Ros. (2011). "What makes a skilled writer? Working memory and audience awareness during text composition". Learning and Individual Differences 21. 505-516.

[2] Al-Omari, O. (2006). An analysis of the Friday sermons discourse: A case study of Jordanian mosques. Unpublished M.A. thesis, Yarmouk University.

[3] Baddeley, A. (2003). "Working memory and language: An overview". Journal of Communication Disorders 36. $189-208$.

[4] Barletta, Manjarres, N. (2007). "Critical Discourse Analysis: A review of critique". Lenguaje. 35(1), 219-242.

[5] Buja, E. (2010). "Academia catavencu: A challenge for discourse analysts". Philology and Cultural Studies 3 (52). 85-94.

[6] Ede, L. (1979). "On audience and composition". College Composition and Communication 30. 291-295.

[7] Fairclough, N. (1995). Critical discourse analysis: The critical study of language. New York: Longman.

[8] Gross, A. (1999). "A theory of the rhetorical audience: Reflections on Chaim Perelman". Quarterly Journal of Speech 85. 203211.

[9] Gregg, N., S. Sigalas, C. Hoy, J. Wisenbaker and C. Mickinley. (1996). "Sense of audience and the adult writer: A study across competence levels". Reading and Writing 8. 121-137.

[10] Halassa, C. (2001). The use of adverbial clauses in the English language of newspapers editorials. Unpublished M.A. thesis, University of Jordan.

[11] Hall, S. (2012). The discourse of Protest: Using discourse analysis to identify speech acts in UK broadsheet newspapers. M.A thesis, London School of Economics and Political Science. Retrieved December, 2, 2012 from http://www2.1se.ac.uk/media@1se/research/mediaWorkingPapers/MScDissertationSeries/2011/69.pdf. 
[12] Jawad, F. (2002). A contrastive rhetorical analysis of editorials in The Jordan Times and The Guardian focusing on thought development and organization. Unpublished M.A. thesis, University of Jordan.

[13] Johnson, R. (1997). "Audience involved: Toward a participatory model of writing". Computers and composition. 14. $361-37$.

[14] Kroll, B. (1984). "Writing for readers: Three perspectives on audience". College Composition and Communication 35. $172-185$.

[15] McQuail, D. (1997). Audience analysis. London: SAGE Publication.

[16] Moji, A. 2011. "A systematic analysis of editorials in selected Nigerian newspapers". Retrieved December, 1, 2012 from http://www.unilorin.edu.ng/studproj/arts/0715CD049.pdf.

[17] McCrimmon, J. (1963). Writing with a purpose. New York: Houghton Mifflin Company.

[18] O'Halloran, K.A. (2005). "Mystification and social Agent Absences: A critical discourse analysis using evolutionary psychology". Journal of Pragmatics, 37, 1945-1964.

[19] Rashidi, N. and Souzandehfar, M. (2010). "A critical Discourse Analysis of the Debates between Republicans and Democrats over the Continuation of War in Iraq". The Journal of Linguistics and Intercultural Education 3(1), 55-82.

[20] Van Dijk, T. (2006). Politics, Ideology and Discourse. Retrieved on April, $5^{\text {th }} 2020$ from http://www.discourses.org/OldArticles/Politics,\%20Ideology\%20and\%20Discourse.pdf.

[21] Witte, S. and L. Faigley. (1981). "Coherence, cohesion, and writing quality". College Composition and Communication 32. 189-204.

[22] Wodak, R. and Meyer, M. (2001). Methods of Critical Discourse Analysis, London: SAGE Publication Ltd.

[23] Yaghoobi, M. (2009). "A critical discourse analysis of the selected Iranian and American printed media on the representations of Hizbullah-Israel war". Journal of Intercultural Communication 21. Retrieved December, 1, 2012 from http://www.immi.se/intercultural/nr21/yaghoobi.htm.

Sanaa Hssni Al-Marayat received her M.A in Linguistics in 2016 from the University of Jordan, Amman/Jordan. She is currently a full time lecturer in the University of Jordan. She has published many research articles. Her major areas of study include discourse analysis, semantics and sociolinguistics. 